\title{
Touristic destination image in light of the service dominant logic of marketing
}

\author{
Imagem de destinos turísticos à luz da lógica dominante do serviço em marketing
}

\author{
Edar da Silva Añaña \\ Universidade Federal de Pelotas, Rua Gomes Carneiro, 1 - Centro - CEP 96010-610 Pelotas, RS, Brazil, edaranana@gmail.com
}

Francisco Antonio dos Anjos

Universidade do Vale do Itajaí, 5ạ Avenida, 1100, Bloco 7, Sala 204 -Municípios - CEP 88337-300 Balneário Camboriú, SC, Brazil, anjos@univali.br

\author{
Melise de Lima Pereira \\ Universidade Federal do Rio Grande, Rua Glicério P. de Carvalho, 81 - Coxilha - CEP 96230-000, Santa Vitória do Palmar, RS, Brazil, \\ melisedelimapereira@gmail.com
}

\begin{abstract}
This paper analyzes the composition and internal arrangement of touristic seaside destinations in Brazil, in light of three not-yet tested theories: the Means-End Chain (Gutman, 1982), the Service Dominant Logic of Marketing (Vargo \& Lusch, 2004), and the organizational triad for local development proposed by Vázquez-Barquero (1999). An internet-based survey was distributed and completed by 178 respondents. The answers concentrated in four (among eight possible) destinations: Balneário Camboriú (31.4\%), Rio de Janeiro (28\%), Torres (20\%) and Natal (8\%). The data were first submitted to Confirmatory Factor Analysis to identify and to validate the set of components representing the Tourism Destination Image - TDI. The TDI constituting factors, and variables representing the Personal Values (as ancestors) and the Consumer Behavior (as descendants), were submitted to a Structural Equation Model to evaluate the TDI internal arrangement and inter-construct relationships. Results indicate that values related to self-respect, security and excitement influence the assessment of some TDI components, and that the last four constructs influence the likelihood of individuals to visit or to recommend the destinations.
\end{abstract}

Keywords: Tourism, tourist destination image, image measurement, means-end theory, Brazil.

\section{Resumo}

Este artigo analisa a composição e o arranjo interno da imagem dos destinos turísticos do litoral brasileiro, à luz de três teorias ainda não testadas: a Cadeia de Meios e Fins (Gutman, 1982), a Lógica dos Serviços Dominantes do Marketing (Vargo \& Lusch, 2004), e a tríade organizacional para o desenvolvimento local proposta por VázquezBarquero (1999). A pesquisa foi aplicada com 178 pessoas. As respostas concentraram-se em quatro (entre oito possíveis) destinos: Balneário Camboriú $(31,4 \%)$, Rio de Janeiro ( $28 \%)$, Torres $(20 \%)$ e Natal $(8 \%)$. Os dados foram submetidos pela primeira vez à Análise Fatorial Confirmatória para identificar e validar o conjunto de componentes que representam a Imagem de Destino de Turismo - TDI. Os fatores constituintes do TDI e as variáveis que representam os Valores Pessoais (como antepassados) e o Comportamento do Consumidor (como descendentes) foram submetidos a um Modelo de Equação Estrutural para avaliar o arranjo interno do TDI e os relacionamentos construídos. Os resultados indicam que os valores relacionados ao auto-respeito, à segurança e à emoção influenciam a avaliação de alguns componentes do TDI e que algumas construções influenciam a probabilidade de os indivíduos visitarem ou recomendarem os destinos.

Palavras-chave: Turismo, imagem de destino turístico, medição de imagem, teoria dos meios e fins, Brasil.

\section{Introduction}

The image of a destination is an important factor taken into account by tourists when choosing a place to visit (Baloglu \& McCleary, 1999; Echtner \& Ritchie, 2003; Gallarza, Saura, \& Garcia, 2002; Pike, 2005) due to its importance in enhancing tourist satisfaction and affecting the intention of tourists to repeat their visit ( Fakeye \& Crompton, 1991; Pike, 2005; Prayag, 2008; Tasci \& Gartner, 2007). Destination image is also related to destination personality assessment and loyalty behavior (Ekinci, Sirakaya-Turk, \& Baloglu, 2007) and to psychological factors like motivation and cultural values (San Martín \& Rodríguez del Bosque, 2008).

A tourist destination is an amalgam of products and opportunities combined to provide an experience, the tourist experience (Murphy, Pritchard, \& Smith, 2000), which is offered and consumed under the brand of the destination. According to Saraniemi \& Kylanen (2011), destinations appear as spaces through which power, identity, meaning, and behavior are constructed, negotiated, and renegotiated according to sociocultural dynamics. A destination is commonly seen as a set of institutions and actors in a physical or virtual space where marketing-related transactions and activities challenge the traditional dichotomy of production and consumption (Saraniemi \& Kylanen, 2011). In this sense, the destination is a construct that takes distinct discursive forms and practices across various spatial and temporal contexts. Destinations are multicultural and globalized markets where various actors produce, maintain, negotiate, and transform meanings while creating destination cultures.

The image of a destination arises from knowledge (functional aspect) and emotions (affective aspect) that an individual or a group has about a particular place. Destination image is a result of previous experience and/or information gathered during the destination selection process (Baloglu \& McCleary, 1999; Echtner \& Ritchie, 2003; Fakeye \& Crompton, 1991) and is significantly affected by an individual's motivation and cultural 
values (San Martín \& Rodríguez del Bosque, 2008). Due to its aptitude to create expectations, the image interferes in tourists' assessments of a destination, favoring or decreasing its likelihood to delight tourists.

Some authors have studied the image of tourist destinations in different countries and contexts (Hui \& Wan, 2003; Pike, 2005; Prayag, 2008; Sahin \& Baloglu, 2011; Tang, Scherer, \& Morrison, 2011; Stylos, Vassiliadis, Bellou, \& Andronikidis, 2016; Zhang, Wu, \& Buhalis, 2017), but some countries/territories like the USA, China, Spain, Turkey, Australia, South Korea, Mauritius, Taiwan, South Africa, Japan, Italy, Malaysia, and Austria have received more attention than others (Nghiêm-Phú, 2014). Studies about destinations in South America are relatively scarce (Hudson, Wang, \& Gil, 2010; Shani, Chen, Wang, \& Hua, 2009), especially in Brazil, a continent-size country with great diversity of destinations, where the studies about this theme are relatively recent and context-specific (Carniello \& Santaella, 2012; Chagas, 2008, 2009, 2010; Pereira, 2013; Pereira, Anjos, \& Añaña, 2014; Pereira, Anjos, \& Añaña, 2016; Anjos, Pereira, \& Tennenberg, 2017).

Previous works proposed scales to determine internal arrangement of attributes to measure the perceived image of destinations. This is the case of Baloglu \& McCleary (1999), Byon \& Zhang (2010), Echtner \& Ritchie (2003), Fakeye \& Crompton (1991), and Pérez-Nebra \& Torres (2010), among others. Chen, Lin, Gao, \& Kyle (2015) improved a scale to evaluate the cognitive image of Taiwan as destination and concluded that it is a composite of common images and two salient dimensionsunique and atmospheric images. Nevertheless, none of these studies dared to validate a universal instrument able to be used everywhere and in any context.

Recent studies tried to improve empirically the understanding of relationships between service's quality at destinations, affective image and re-visit intention, including the examination of the moderating effect of past experience (Tosun, Bora, \& Fyall, 2015); or testing the destination image across residents and tourists (Stylidis, Shani, \& Belhassen, 2017), or even verifying the triangular relationships among the country image, the destination image, and the Olympic Games image using a random sample gathered by Amazon Mechanical Turk (MTurk), an internet-based tool destined to capture opinions amongst survey takers (Hahm, Tasci, \& Terry, 2018).

Stylidis et al. (2017), addressed methodological issues about the measurement of destination image. The caractheristics and number of attributes used to capture destination image till then had many variations, suggesting a lack of agreement about its measurement. They suggested that destination image still requires improvements to advance towarad an universal framework of measurement.

Besides the efforts done in previous investigations, the empirical studies carried out to date seem insufficiently theorybased, resulting in a lack of conceptual framework (Beerli \& Martín, 2004; Stylidis et al., 2017). Beerli \& Martín (2004, p.
659), assume that "the selection of the attributes used in designing a scale will depend largely on the attractions of each destination, on its positioning, and on the objectives of the assessment of perceived image." This work focuses on the cognitive image measurement, one of the least studied areas in this field of research (Baloglu \& McCleary, 1999).

This research goes farther, but does not contradict traditional approaches regarding the internal arrangement of destination image components, such as the cognitive-affective-conative hierarchy proposed by Gartner (1993), the cognitive-affectiveoverall composition proposed by Baloglu \& McCleary (1999), the three dimensional structure proposed by Echtner \& Ritchie (2003), or the core-periphery structure proposed by Lai \& Li (2012).

This work tries to fill the gap of knowledge regarding "the customer point of view," the third dimension proposed by Mazanec (1994), by exploring three theories not yet tested in this field of study. As far as we know, this is the first attempt to analyze the internal layout of destination image vis-à-vis the Means-End Chain (Gutman, 1982), the Service Dominant Logic of Marketing (Vargo \& Lusch, 2004), and the organizational triad for local development proposed by Vázquez-Barquero (1999).

The research is exploratory in essence and innovates over previous studies for testing the destination image as a "satisfier for needs and wants" and not as a construct "out there." According to this view, customers do not assess a destination "by its colors and lines," as a distant picture that people evaluate cognitively or affectively, but as an organized system of features that people assess by its aptitude to deliver "benefits to me."

The main objectives of this work are (1) to validate a scale for assessing the cognitive image of coastal destinations in Brazil, with different portfolios of resources and attractions, and (2) to propose an alternative arrangement for destination image in light of three theories not yet tested in studies of destination image, and in this way, fill the gap regarding the third dimension proposed by Mazanec (1994) that was not discussed in previous works.

\section{Image of tourist destinations}

The image of a place is an important component that managers have to deal with due to its influence in creating expectations (Matos, Mendes \& Valle, 2012) and the role it plays in the tourist's decision when choosing a destination to visit. Image is one of the main assets of a tourist destination and one that most influence3.s tourists' decisions when choosing a destination (Echtner \&Ritchie, 2003; Gallarza, Saura \& García, 2002). Since image is a key factor for selecting a destination, it is very important that managers know which features strengthen the image of a destination and the nature of managerial strategies that should be adopted to increase competitiveness without neglecting appropriate sustainable practices (Ekinci, Sirakaya-Turk \& Baloglu, 2007).

Destination image can play an important role in travel decisions (Pike, 2008) and is an important antecedent of tourist satisfaction 
(Chagas, Sampaio, \& Santos, 2013). The image construction process of a tourist destination includes knowledge (functional aspect) and emotions (affective aspect) that an individual or a group has about a place, resulting from his/her accumulated experiences or by the information gathered during the destination selection process (Fakeye \& Crompton, 1991; Echtner \& Ritchie, 2003; Baloglu \& McCleary, 1999).

The image of tourist destinations has been studied for decades by various researchers (Echtner \& Ritchie, 2003; Fakeye \& Crompton, 1991; Baloglu \& McCleary, 1999; Gallarza, Saura \& García, 2002; Pike, 2008). According to Byon and Zhang (2010), over the last three decades many researchers have identified variables representing the destination image of a particular location, a majority of which have adopted cognitive image components.

For Gallarza, Saura and García (2002), despite its relevance for tourism marketing, the research on Tourism Destination Image faces many difficulties. The most visible difficulties refer to the complexity and multidimensionality of tourism products, the necessity of consumers physically moving to the behavior scenario, and the great subjectivity of tourism services (images are mixed with impressions about residents, retailers, other tourists, and/or employees); but more important is the intangibility of services that does not permit an objective assessment before visiting or selecting the destination (Fakeye \& Crompton, 1991).

For Buhalis (2000), destinations are amalgams of tourism products that offer an integrated experience to consumers. Traditionally, destinations are regarded as well-defined geographical areas, such as a country, an island or a town. However, a destination can also be a perceptual concept, interpreted subjectively by consumers, depending on their travel itinerary, cultural background, the purpose for visiting, educational level and past experience.

According to Matos, Mendes \& Valle (2012), the image of a destination lies on two types of components, those that are attribute-based and those that are holistic, and each of these components contains functional, or more tangible, and psychological, or more abstract, characteristics (Baloglu \& McCleary, 1999; Echtner \& Ritchie, 2003). For Gartner (1993), the construct is hierarchically formed by cognitive, affective, and conative/behavioral components. The cognitive or perceptual component refers to the beliefs or knowledge about a destination's attributes evaluations; the affective images refer to the motives one has in choosing a place to visit, or "what we wish to obtain from the object being considered" (p. 196); and the behavioral component relates to the actions of individuals, like the probability of visiting or recommending a destination.

Despite efforts to improve methods to evaluate destination image, this subject is still ongoing. For Jenkins (1999, p. 5), "one of the basic problems of tourist destination image research is that destination images are 'holistic' representations of a place and that in attempting to measure them, researchers are compelled to look at the parts or attributes singularly". Echtner
\& Ritchie (2003) also criticize the intensive use of structured methodologies since they are attribute-focused, and therefore respondents are forced to think about product image in terms of the attributes specified by the scales instead of being able to express their holistic impressions about the destination.

Taking into consideration the difficulty in comparing destinations through their own unique characteristics, this work focuses on the cognitive attributes arrangement in light of three related theories: the Means-End Chain (Gutman, 1982), the Service-Dominant Logic of Marketing (Vargo \& Lusch, 2004), and the Local Economic Development framework (VázquezBarquero, 1999). The inclusion of these three theories in this research is innovative, not for theoretical novelty, but for their inclusion in this field of study. An alternative model for destination image components, adapted from Tasci \& Gartner (2007), is detailed in the next section.

\section{Destination Image Construction}

The process of destination image construction comprises different approaches. For Mazanec (1994), destination image is a three-dimensional construct that derives from (a) the evaluation criteria, (b) the evaluated object and (c) the respondent point of view. For Gallarza, Saura and García (2002), there are two approaches to be considered in the image configuration process: static and dynamic. The static approach involves the study of the relationship between image and tourist behavior such as satisfaction and destination choice; the dynamic approach is the interest in the structure and formation of the destination image itself.

The image of a place depends on many objective, subjective and social factors. An objective factor may be something tangible, such as climate, for example, and a subjective factor refers to the affective or emotional interpretation of destination characteristics; social factors refer to the perceptions or beliefs regarding the interaction between tourists and residents (e.g., the political situation or attitude toward tourism and tourists in the place). The destination image is context-specific, which means that tourist perceptions may vary according to the destination (Byon \& Zhang, 2010), and it is formed according to the personal experience and/or from the sources consulted, even in the absence of any commercial information (Tasci \& Gartner, 2007).

According to Echtner and Ritchie (2003), the process of image formation comprises two important phases. Initially people have an organic image, an image assimilated from non-touristic, non-commercial sources, such as the general media (news reports, magazines, books, movies, TV), education (school courses) and the opinions of family/friends. In a second step, this mental construct may be influenced by commercial sources of information, such as travel brochures, agents and guidebooks regarding the destination, and the organic image may be transformed into an induced image. 
According Tasci \& Gartner (2007), the image is a mental representation of a tourism destination on the basis of information cues delivered by agents and selected by a person. Image uniqueness occurs due to many variables, including culture, prior experience and needs to be met. Three types of agents contribute to its formation: (1) supply-side (destination), (2) autonomous (independent), and (3) demand-side (perceivers). Destination image has direct effects on consumer behavior; destination image has been linked to effects on pre-, during-, and post-trip consumer behavior.

This work espouses the same logic of Tasci \& Gartner (2007) but goes farther. We also assume that destination image is a complex construct formed by autonomous, induced and organic components, that destination image is an important aspect of tourism development due to its impact on both supply- and demand-side aspects of marketing, that destination image has direct effects on consumer behavior, and that every destination has a unique image capital resulting from the landscape, history and traditions, cultural patterns, community values, etc.

However, our model differs from the one proposed by Tasci \& Gartner (2007) in two important aspects: (a) we presuppose that 'personal values' can be used as a proxy for 'perceiver characteristics' since they represent the most stable component of culture and are easier to measure, and (b) we assume that a destination image can be better seen by the availability of resources (operand and operant) and/or by its organizational components (software, hardware and orgware) than by the cognitive/affective/overall framework. Personal values, destination resources and destination components are discussed in depth in the next sections. A simplified model of Destination Image and its relationships is presented in Figure 1.

Figure 1 - Model of Destination Image and its relationships

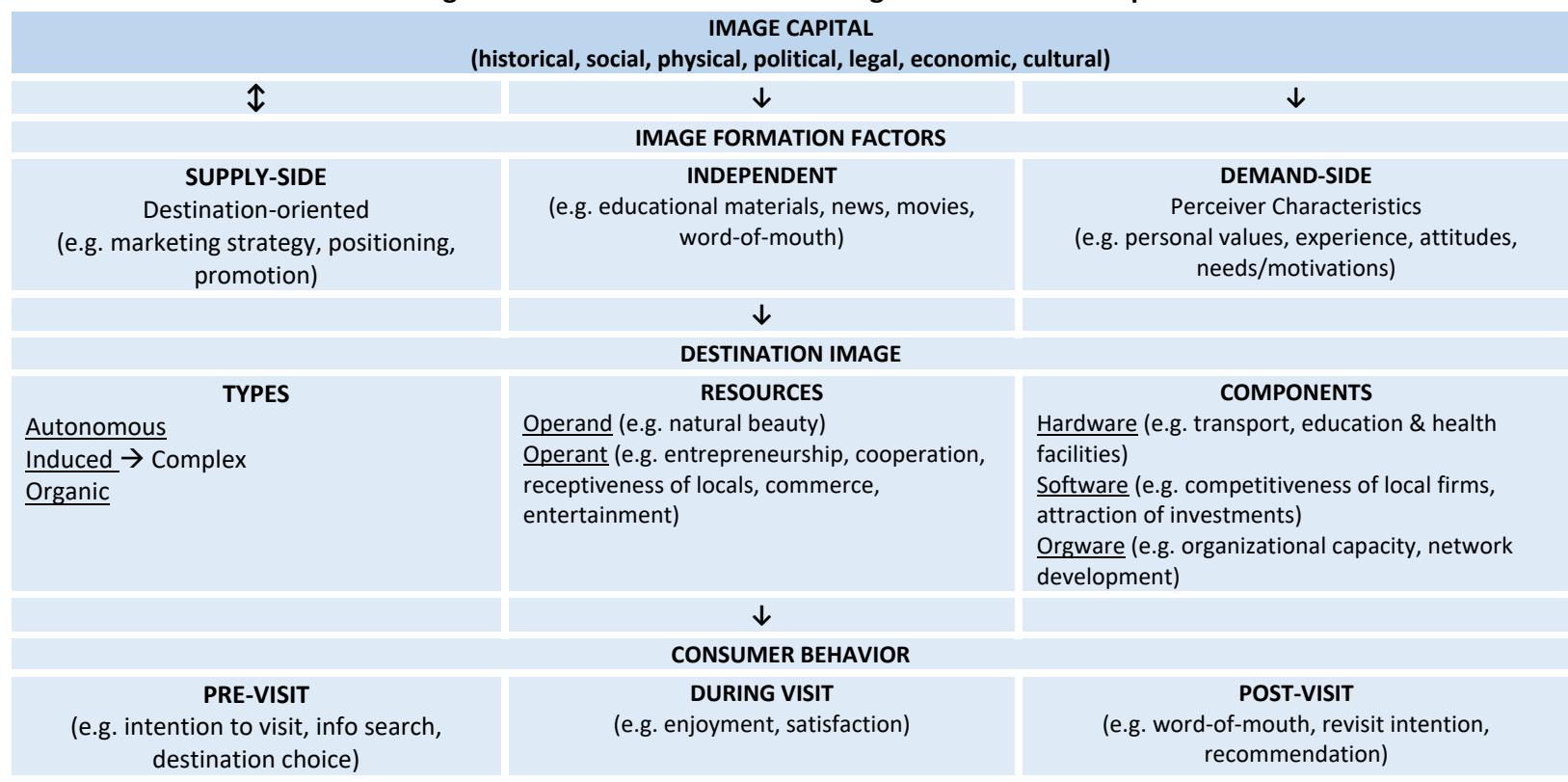

Source: Adapted from Tasci \& Gartner, 2007.

\subsection{The influence of personal values in consumer behavior: the means-end chain}

The influence of personal values in consumption decisions has appeared in the research agenda for four decades, but its presence in tourist destination literature is still scarce. Matos, Mendes \& Valle (2012) found evidence that "personal factors" influence the way tourists perceive and evaluate destinations; however, the factors to which they refer are motivation and travel experiences, not personal values. Travel motivation is much more similar to attitude than personal values.

According to Rokeach (1968, p. 550), "attitude is an enduring organization of several believes focused on a specific object (physical or social, concrete or abstract) or situation, predisposing one to respond in some preferential manner." Values are stable and foundational; they are end-states of existence that drive modes of conduct, telling us what attitudes we should hold, what is right and wrong, and transcending specific situations.

Tasci \& Gartner (2007) concede that although there is a lack of research on this subject, destination image must be related to culture given that "the same environmental cue would have different connotations for different cultures resulting in multiple interpretations and meanings" (p. 423). For these authors, people's sociodemographic and cultural characteristics define their needs and motivations, and these needs and motivations influence the way people perceive the characteristics of a destination. Destination image consists of organic (demand side), induced (supply side), and autonomous elements that, together, become a complex amalgam not always easily interpreted.

This research differs from previous works, not only for testing TDI in light of personal values, but for introducing a structured 
approach based on the hierarchy of resources perceived at destinations. According to this approach, destination attributes can be better perceived according to the capacity to provide final benefits to tourists by the destination resources (Vargo \& Lusch, 2004; Vásquez \& Barquero, 1999) and not by the triad cognitive-affective-global image (Baloglu \& McCleary, 1999).

Values represent (1) concepts or beliefs (2) about desirable end states or behaviors (3) that transcend specific situations, (4) guide selection or evaluation of behavior and events, and (5) are ordered by relative importance (Schwartz \& Bilsky, 1990). "A value is a standard or criterion that serves a number of important purposes in our daily lives; it is a standard that tells us how to act or what to want; it tells us what attitudes we should hold; it is a standard we employ to justify behavior and to morally judge" (Rokeach, 1968, p. 550).

The Means-End Chain Theory (MECT) introduced by Gutman (1982, p. 68) assumes that (1) values, as desirable end-states of existence, play a dominant role in guiding choice patterns, and that (2) people cope with great diversity of potential satisfiers of their values. The Means-End Chain is focused on the linkage between where a person wants to be and the means chosen to get there. "A product is indeed a bundle of attributes, and people do consume products for desirable consequences they get (trading off with any undesirable consequences)". For Vinson, Scott, \& Lamont (1977), values are centrally held cognitive elements which stimulate motivation for behavioral response. Values existed in a structural hierarchy in which global values connect to consumption-related values, which in turn connect to product (or brand) attributes. Differences in value systems influence the activity preferences of tourists when visiting a destination. Individuals who value personal success and enjoyment/excitement, for example, also appear to value outdoor activities; and individuals who value personal achievement are less likely to define themselves ancestrally and therefore de-emphasize that aspect of travel behavior (Madrigal \& Kahle, 1994).

Pike (2008) argues that destinations are places where people travel to satisfy needs and wants and therefore should be seen as satisfiers of physical needs (relaxation, security, etc.), psychological needs (belonging, esteem, self-actualization, etc.) and intellectual needs (knowledge, aesthetics, contemplation of nature, etc.). The association between the attributes seen in a destination's brand, the desired consequences of tourism experiences and personal values, is in accordance with Reynolds, Gengler, \& Howard (1995) who advocate that consumers attribute meanings to brands according to the consequences they see in the brands used and their personal values systems. Therefore "marketers should consider visitors' personal values when segmenting markets and planning communication strategies, since knowledge of personal values provides an indication of the motives and needs satisfied by a destination" (Madrigal \& Kahle, 1994, p. 27).
The influence of personal values in travel decisions was reinforced recently by Jiang, Scott, \& Ding, (2014) who found evidence that leisure tourists travel in search of some kind of benefit (or consequences) according to the values they want to satisfy. According to these authors, tourists who emphasize pleasure tend to be more interested in enjoying natural scenery and visiting historical, cultural and artistic attractions while tourists that value self-realization and self-improvement prioritize selfenrichment by increasing their knowledge and experience.

A tourist product is an amalgam of tangible and intangible components - a package - based on the activity at the destination. "The package is perceived by tourist as an experience at a price" (Middleton \& Clarke, 2001,p. 125). The components of a package include destination attractions and environment, the facilities and services, the accessibility to the destination, the images of the destination, and the price to the consumer. Therefore, we can assume that a destination can be seen like any other product since it is organized around a touristic attraction - the core product - in a multilevel structure, from the central benefit to the encapsulating shell of involvement (Kotler, Bowen, \& Makens, 2014; Smith, 1994), or even as a combination of all products, services and experiences provided locally (Buhalis, 2000).

In summary, the above theory suggests that values drive personal needs and wants (the ends); therefore, people evaluate destinations according to the availability of means (e.g. natural resources, cultural heritage, mobility, services in general, etc.) to satisfy their priorities (e.g. entertaining, relaxing, enjoying the beauty, learning from other cultures, etc.).

\subsection{Tourist destinations as satisfiers of needs and wants}

Two other important theories contribute to the purpose of this work: the Service-Dominant Logic of Marketing (Vargo \& Lusch, 2004) and the organizational triad for local development (hardware, software and orgware) proposed by VázquezBarquero (1999). The Service-Dominant Logic of Marketing (SDLM) is an approach that emerged from the seminal work of Vargo \& Lusch (2004), proposing that marketing is customercentric and market driven.

According to this line of thought, value is not embedded in the product but in the experiences that products can deliver. Value is an experiential concept, a benefit, an increase in the wellbeing of a particular actor, and not a service or a particular resource (Lusch \& Vargo, 2014). Value is created throughout the relationship between customers and the suppliers or service providers, and the main goal for the companies is customizing their offerings to maximize customers' involvement and suit resources to their needs (Johns, 2008).

According to Vargo \& Lusch $(2004$, p. 3), it is important to understand that not all the resources are able to produce final outputs. In SDLM, "it is not the resources themselves that are the 'inputs' to the production process, but only the services that the 
resources can render". That is to say, resources "are not" inputs; they "become" inputs for tourism products and services.

In SDLM, some resources require other resources to act on them to provide benefits; these "operand" resources are just "potential" resources, but they are unable to create outputs. In the past, resources like land, minerals or natural beauty (for the tourism industry) were seen as symbols of wealth for being finite, but this idea has almost run its course. In the servicecentered economy, those resources are considered potential fonts of wealth, but ones which are unable to produce benefits by themselves. To produce benefits, the potential resources need to be managed, organized, modified, offered to the right audience, exchanged, etc. by the "operant" resources.

For Vargo \& Lusch $(2004$, p. 3), "operant resources are often invisible and intangible; often they are core competences or organizational processes." Due to their capacity to reproduce, they are likely to be dynamic and infinite. Human skills and capabilities are common examples of operant resources (Lusch \& Vargo, 2014). In the tourism industry, we can point to technology, entrepreneurship, interfirm cooperation, receptiveness of locals, commerce, services, and entertainment structures as examples of operant resources.

For the above definitions, we can assume that in tourist destinations some resources can be seen as operand and operant simultaneously. Factors like shopping structure and cultural activities exist primarily for residents but can also be addressed to serve tourists. For the residents, these kinds of factors are operant resources, since they transform operands into benefits independently of touristic activity; however, from the viewpoint of the tourism industry, those resources are simply potential resources since if they are not undertaken, organized, communicated and included in tourism routes those resources will not be able to provide any reward for tourists.

In SDLM, tourists act as co-producers of their own experience and not as passive buyers. In consequence, it is reasonable to expect that they evaluate destinations by the portfolio and quality of resources (operands and operants) available at the "theatre" to satisfy their needs and wants, including costs and rewards. Further, taking into consideration that according to $\mathrm{MECT}$, brands/products are means to satisfy values, it is also reasonable to expect that personal values influence the assessment of destination resources, and these influence consumer behavior (choice, satisfaction, intention to recommend or revisiting, etc.).

Another approach that may contribute to the understanding of this phenomenon is the framework proposed by Vázquez-Barquero (1999) to explain regional endogenous development. According to that framework, the economic 'hardware' is represented by the basic infrastructure such as transport and communication networks, as well as infrastructure for the development of human capital, such as education, health, and cultural facilities; the 'software' is the construction and implementation of comprehensive and sustainable development strategies, including the competitiveness of local firms, the attraction of investments and the advancing of human capital.

The 'orgware' is formed by the organizational capacity, which fosters the involvement of local stakeholders, develops networks and partnerships, and co-ordinates actions at different levels of government (Spenceley, 2008). For Rodríguez-Pose (2010), the 'orgware' is an important component for local endogenous development, since it creates the necessary conditions for investment, economic interaction and trade, reducing the risk of social and political instability and conflict, and lowering uncertainty and information costs.

Even though not originally conceived for tourism destination assessment, this framework can be borrowed to this purpose. Taking into consideration that most of the destinations are places where people travel to satisfy needs and wants (Pike, 2008), it seems reasonable to expect that personal values influence the assessment of destination components (hardware, software and orgware), and these influence consumer behavior (choice, satisfaction, recommendation, revisiting, etc.).

In summary, the above theory suggests that people evaluate destinations according to the abundance of hardware/operand resources (e.g. nature, cultural heritage, transportation system, etc.), software/operant resources (e.g. technology, commerce and services, entertainment, etc.) and orgware (e.g., mobility, government organization for tourism, receptivity of residents, etc.) to satisfy their needs and wants.

\section{Hypothesis}

Tourism destinations are brands and satisfiers of needs and wants at the same time. The image of destinations refers to the perceptions of tourists in a destination and these correspond to the perceived contribution of the different tourism services to be found there: accommodation, food, transport, and more (Gallarza, Saura \& García, 2002). In consequence the image must be congruent with the triad proposed by Vázquez-Barquero (1999), and/or with the dyad of resources proposed by Vargo \& Lusch (2004). Accordingly, it seems reasonable to expect that:

H1 - The image of a touristic destination is organized into three groups of factors representing the hardware/operand resources, the software/operant resources and the orgware.

According to Matos, Mendes \& Valle (2012), the destination image results from a continuum of mental processes in which two different groups (uncontrollable and controllable) forces emerge. The uncontrollable forces emerge from the social and psychological characteristics of the tourist, the residents and the service providers' attitudes towards tourism activity as well as the interaction between tourists at a foreign destination. In general, these forces are beyond the control of tourism stakeholders.

Controllable forces correspond to promotion efforts, access routes and tourism infrastructures, built and prepared by stakeholders and marketers to stimulate tourists to visit their 
destination. The image of a destination is primarily formed by autonomous agents, such as newspapers, televised news, and television in general, which represents the most important source of information (Govers, Go, \& Kumar, 2007). Contrary to Beerli \& Martín (2004), who focused on the postvisit image, Govers, Go \& Kumar (2007) prove that secondary sources of information are essential agents influencing the previsit image.

Therefore, it is reasonable to expect that:

H2 - The evaluation of uncontrollable forces, like the hardware or operand resources, influences the assessment of controllable forces, like the software or operant resources.

Personal values are important precursors of perceived image since they correspond to the innermost (and the most stable) element of culture and therefore influence consumers' behavior and choices. Personal values shape our priorities in life (i.e. belonging, excitement, security, accomplishment, etc.) and consequently influence the way we assess brands and goods as "appropriated for me" or "not for me" (Madrigal \& Kahle, 1994). Tourism destinations are brands and satisfiers of needs and wants at the same time, and taking into consideration that people consume to satisfy personal values we can expect that:

H3 - Values related to personal gratification (or selfishness) such as self-fulfillment, accomplishment or self-respect influence the evaluation of attributes related to personal satisfaction, like residents' openness, value for the money and others.

H4-Values related to the uncertainty avoidance, or the preference for security, influence the evaluation of factors related to the physical protection and conformity with stated rules.

H5 - Values related to the preference for fun and excitement influence the evaluation of factors related to entertainment.

H6 - Values related to in-group association, as the sense of belonging and warm relationships with others, influence the assessment of factors related to the interaction with residents and their traditions.

The core of marketing is to understand what motivates a consumer to buy a product, and on these criteria, MECT has advantages compared with other approaches and deserves more attention and application in travel motivation research (Jiang, Scott \& Ding, 2015). Clearly the perception of a destination may be significantly influenced by psychological factors, such as motivation and cultural values (San Martín \& Rodríguez del Bosque, 2008). In this sense, the MECT approach allows a deeper understanding of why certain activities are undertaken while travelling (Jiang, Scott \& Ding, 2015). At the same time image evaluation is an important precursor for tourists' satisfaction and repeat-visit intentions (Pike, 2008; Tasci \& Gartner, 2007). As such, it is possible to expect that:

H7 - Factors encompassing expected benefits at destination like mobility, entertainment, services in general and welcomeness influence the likelihood that tourists will visit and/or recommend the destination.
The choice of a holiday destination is considered a high involvement purchase since consumers spend a great amount of time and money on that decision (Matos, Mendes $\backslash \&$ Valle, 2012). According to Hallmann, Zehrer, \& Muller (2013), although still significant, value for money plays one of the least important roles for image formation. Therefore, we can expect that:

H8 - The price of services comprises a value for money factor, but its influence on decisions regarding to visit or to recommend the destination is not significant.

\section{Method}

This research can be characterized as an exploratory and hypothesis-testing work. The approach is predominantly quantitative, preceded by an exploratory stage (qualitative) conceived to elicit the set of variables to be inserted into the questionnaire, to capture the different facets of cognitive image and evaluate the hypothesized relationships. The measurement procedure can be typified as a structured method according to the taxonomy proposed by Gallarza, Saura and García (2002) since it merges statistical processes with multivariate and bivariate analysis.

The set of TDI variables was gathered from previous works like Fakeye \& Crompton (1991), Echtner \& Ritchie (2003), Beerli \& Martin (2004), Pérez-Nebra \& Torres (2010) and Pereira (2013) and submitted to the evaluation of two experts for amendments; the set of personal values was imported from the List of Values (Madrigal \& Kahle, 1994) and the consumer behavior was represented by two declared variables: likelihood to visit and likelihood to recommend the destination in assessment. Variables comprising the List of Values (sense of belonging, being well respected, security, fun and enjoyment in life, excitement, sense of accomplishment, self-fulfillment, selfrespect, warm relationship with others) were surveyed as rank order questions, and the TDI attributes and the likelihood to visit and to recommend were collected as semantic differential questions (seven alternatives), ranging from 'certainly not' $(-3)$ to 'certainly yes' (+3).

Data were collected through an internet-based questionnaire including demographics, tourism preferences, and a list of coastal destinations available for evaluation. Respondents were asked to evaluate one of the following destinations: Balneário Camboriú, Fortaleza, Jijoca de Jericoacara, Maceió, Natal, Pipa, Rio de Janeiro and Torres. A total of 177 valid answers were received and analyzed. Data analysis involved three steps: (1) monovariate and descriptive analysis, (2) exploratory/confirmatory factor analysis, E/CFA of TDI variables, to evaluate reliability and validity of actors representing that construct, and (3) Structural Equation Modeling, to analyze TDI internal arrangement and its relationship with personal values (as causes) and consumer behavior (as effects).

\section{Results}

The sample was $61 \%$ female, $37.9 \%$ male and $1.1 \%$ that did not declare sex. Most of the 178 respondents were students of management or tourism careers $(27.1 \%)$, students of other 
areas (22.6\%), tourism industry professionals $(7.9 \%)$ and employees of commerce and services in general (4.5\%). They were residents of Rio Grande do Sul (76.8\%), Santa Catarina (9\%) and São Paulo (7.9\%).

The assessment of the proposed hypothesis was performed in two steps involving (1) an E/CFA to adjust and validate the TDI measurement model, and (2) a Structural Equations Model to test the hypothesized relationships. Both steps were performed with MPlus software. Data failed to pass the KolmogorovSmirnov test (for normality), and for that reason the analysis was performed with the Robust Maximum Likelihood (MLR) Estimator, for being one of "the most commonly used estimator for non-normal continuous data" (Brown, 2006, p.379).
Results suggest that the TDI of Brazilian coastal destinations can be analyzed across seven dimensions: (1) A safe and welcoming environment - SWE; (2) Landscape; (3) Entertainment; (4) Cultural Heritage; (5) Commerce and Services - C\\&S; (6) Mobility; and (7) Value for Money. Almost all the TDI factors showed Composite Reliability (CR) and Average Variance Extracted (AVE) over the minimum recommended 0.70 and 0.50 respectively; the only exception was Landscape AVE, the value for which was slightly different from the minimum expected. Values of estimates, CR and AVE of all factors and variables are presented in Table 1.

Table 1 - Measurement Model of Tourism Destination Image.

\begin{tabular}{|c|c|c|c|c|c|}
\hline Factors and Attributes & Estimate & S.E. & Est./S.E. & Standardized Estimate & C.R./A.V.E. \\
\hline \multicolumn{5}{|c|}{ Safe and welcoming environment - SWE } & \multirow{6}{*}{$\begin{array}{l}0.857 / \\
0.548\end{array}$} \\
\hline A safe and secure environment & 1.000 & 0.000 & 999 & 0.632 & \\
\hline A clean and tidy environment & 1.116 & 0.135 & 8.297 & 0.795 & \\
\hline Pleasant weather & 1.214 & 0.135 & 8.985 & 0.841 & \\
\hline Friendly and helpful people & 0.800 & 0.139 & 5.749 & 0.719 & \\
\hline A tranquil and restful atmosphere & 1.023 & 0.139 & 7.355 & 0.697 & \\
\hline \multicolumn{5}{|c|}{ Landscape } & \multirow{5}{*}{$\begin{array}{l}0.774 / \\
0.464\end{array}$} \\
\hline Gorgeous gardens and springs & 1.000 & 0.000 & 999 & 0.705 & \\
\hline Scenic drives & 0.849 & 0.113 & 7.493 & 0.684 & \\
\hline Breathtaking scenery and natural attractions & 0.540 & 0.141 & 3.836 & 0.559 & \\
\hline Picturesque parks/lakes/rivers & 1.068 & 0.096 & 11.125 & 0.761 & \\
\hline \multicolumn{5}{|c|}{ Entertainment } & \multirow{6}{*}{$\begin{array}{c}0.923 / \\
0.705\end{array}$} \\
\hline A wide array of shows/exhibitions & 1.000 & 0.000 & 999 & 0.855 & \\
\hline Tempting cultural events and festivals & 0.971 & 0.063 & 15.325 & 0.816 & \\
\hline Excellent country/folk music & 0.994 & 0.051 & 19.438 & 0.906 & \\
\hline Colorful nightlife & 0.974 & 0.073 & 13.360 & 0.808 & \\
\hline A wide variety of entertainment & 0.836 & 0.072 & 11.563 & 0.809 & \\
\hline \multicolumn{5}{|l|}{ Cultural Heritage } & \multirow{3}{*}{$\begin{array}{c}0.847 / \\
0.735\end{array}$} \\
\hline A distinctive history and heritage & 1.000 & 0.000 & 999 & 0.837 & \\
\hline Vintage buildings & 1.021 & 0.106 & 9.616 & 0.877 & \\
\hline \multicolumn{5}{|c|}{ Commerce and Services - C|\&S } & \multirow{4}{*}{$\begin{array}{c}0.887 / \\
0.724\end{array}$} \\
\hline A wide selection of restaurants/cuisine & 1.000 & 0.000 & 999 & 0.866 & \\
\hline A wide variety of shop facilities & 1.079 & 0.072 & 14.990 & 0.874 & \\
\hline A wide choice of accommodations & 0.899 & 0.065 & 13.855 & 0.811 & \\
\hline \multicolumn{5}{|c|}{ Mobility } & \multirow{5}{*}{$\begin{array}{l}0.758 / \\
0.513\end{array}$} \\
\hline $\begin{array}{l}\text { Well-communicated traffic and } \\
\text { parking information }\end{array}$ & 1.000 & 0.000 & 999 & 0.728 & \\
\hline Downtown parking & 1.250 & 0.139 & 8.962 & 0.784 & \\
\hline Easy access to the central areas & 1.125 & 0.143 & 7.890 & 0.743 & \\
\hline Easy-to-use and affordable transport system & 0.900 & 0.115 & 7.809 & 0.611 & \\
\hline \multicolumn{5}{|c|}{ Value for money } & \multirow{5}{*}{$\begin{array}{l}0.872 / \\
0.632\end{array}$} \\
\hline Reasonable prices for food and accommodation & 1.000 & 0.000 & 999 & 0.894 & \\
\hline Good value for money & 0.775 & 0.064 & 12.177 & 0.819 & \\
\hline Reasonable prices for attractions and activities & 0.824 & 0.069 & 11.895 & 0.803 & \\
\hline Good bargain shopping & 0.723 & 0.088 & 8.200 & 0.644 & \\
\hline
\end{tabular}

According to Hypothesis 1 and Hypothesis 2, it was expected that components of TDI could be organized in different groups representing the hardware/operand resources, the software/operant resource and the orgware/benefits generators, and that uncontrollable forces could in some way drive the controllable ones.
In order to check those propositions, the TDI components were tested one-by-one as possible predictors for all others and were organized in three groups according to the significant relationships detected. As we can see in Figure 2, all three groups could be identified according to the theory. The only 
exception was Landscape, a notorious operand resource that showed no significant influence on other TDI dimensions.

The evaluation of the first two hypotheses required some care due to the subjectivity that is implicit in its assessment, but regardless of that constraint, the Hypothesis $\mathrm{H} 1$ was supported since all the three groups identified were in accordance with the theory. Hypothesis $\mathrm{H} 2$ was partially supported since the Cultural Heritage showed significant influence in the assessment of Entertainment and C\\&S, but Landscape did not.

This result is in accordance with Echtner \& Ritchie (2003) who assert that destination images seem to be derived from a much wider spectrum of information sources than other products. TDI is rooted in the country image, and due to this theoretical basis, it is gleaned primarily from non-commercial sources (historical, political, economic and social factors), creating an organic image that is improved afterwards by specialized fonts (touristic communication), creating an induced image. Therefore, it seems reasonable that a positive image of operand/hardware resources (e.g., landscape, tangible and intangible heritage, etc.) benefits the image of operant/software resources.

Hypotheses $\mathrm{H} 3, \mathrm{H} 4$ and $\mathrm{H} 5$, regarding the influence of personal values in TDI components, were all supported. As we can see in Figure 2 , the assessment of self-respect contributes $12.5 \%$ of its value to the welcoming environment; and in the same way, the preference for excitement contributes $10 \%$ to the evaluation of the entertainment structure. In an opposite route, the preference for security influences negatively $(-0.155)$ the assessment of Cl\&S structure. Hypothesis 6 was not confirmed, since no influence was found on values related to the sense of belonging and warm relationships in TDI components representing possible interaction with residents or their traditions.

Besides the hypothesized relationships, all other five values were also tested as possible predictors of TDI components as a measure of precaution, but no coincidence was found. Results of these additional tests were omitted from Figure 2 to improve its readability.

Hypothesis 7, regarding the supposition that factors related to direct benefits at destination, like welcomeness, mobility, services and entertainment that influence consumer behavior, was only partially supported. As we can see in Figure 2, a safe and welcoming environment and the entertainment structure influence both the likelihood to visit and to recommend the destination; but the $C \backslash \& S$ structure did not show any influence on those intentions. Mobility does not push directly declared intentions of consumer behavior but an important portion of its evaluation is transferred by the Safe and Welcoming Environment factor to the Likelihood to Visit (0.467) and to the Likelihood to Recommend (0.370) the destination. These indirect effects were not shown in Figure 2 to improve picture readability.

Figure 2 - Structural Relationships

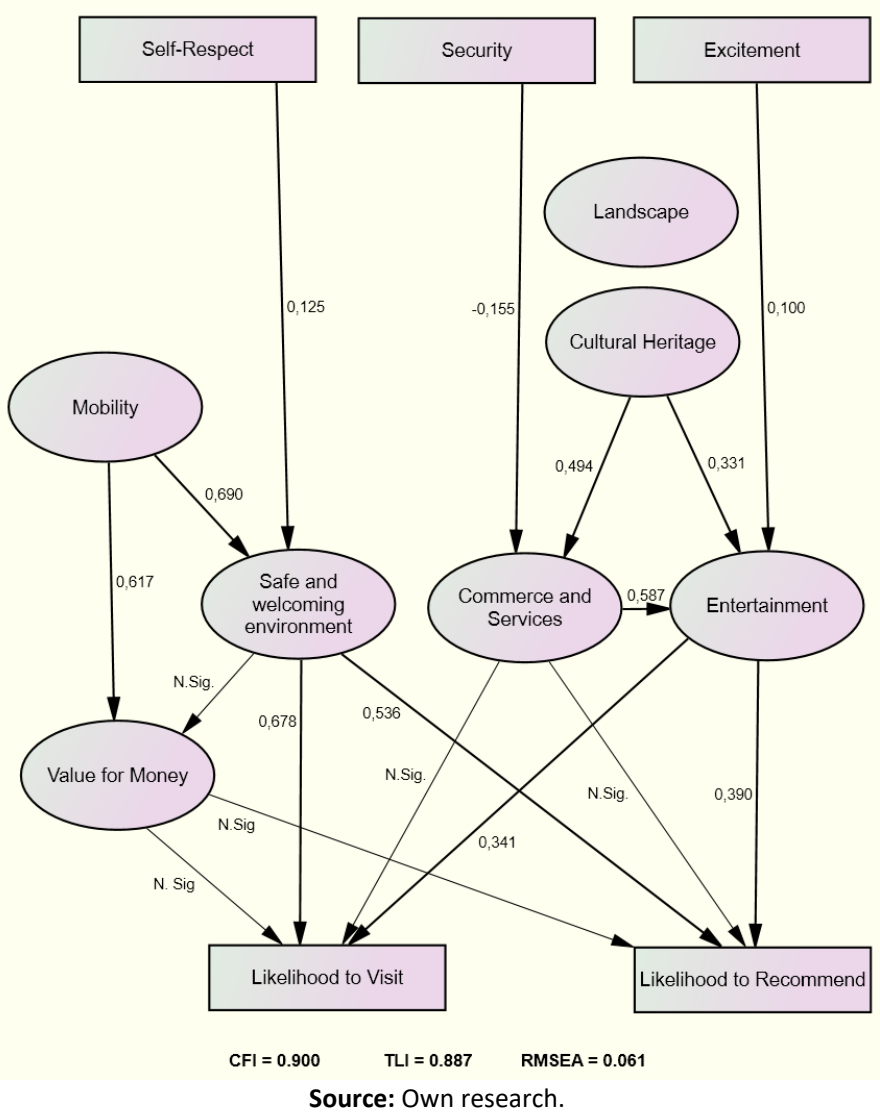


Hypothesis 8, regarding the autonomous existence of the Value for Money factor, was also supported. As seen in the Figure 2, the assessment of Value for Money is strongly dependent on Mobility, but this influence is not converted into visiting intentions.

An unexpected influence of $C \backslash \& S$ in the Entertainment assessment was also identified. Although not hypothesized, this relationship makes complete sense given that some people ascribe high pleasure in shopping/eating/resting during their trips, and that some entertainment activities depend on C $\ \& S$ to exist.

\section{Conclusion}

This work analyzed TDI elements in search for a reliable scale to measure the construct and for a better understanding of the internal arrangement of its components. Seven dimensions of analysis were identified: landscape, cultural heritage, entertainment, commerce and services, safe and welcoming environment, mobility and value for money. All the factors of $\mathrm{CR}$ and $\mathrm{AVE}$, and the overall FIT measures ( $\mathrm{CFI}=0.900$; $\mathrm{TLI}=0.887$; RMSEA $=0.061$ ) matched or surpassed the minimum recommended; one AVE was found moderately deficient and was retained due to the exploratory character of this work.

Except for Landscape, which was identified as a stand-alone factor, all other TDI dimensions are interconnected someway: Urban Mobility improves the feeling of Safe and Welcoming Environment and the assessment of the Value for Money; evaluation of $C \backslash \& S$ contributes to the Entertainment assessment; and the Cultural Heritage contributes both to the $C \backslash \& S$ and to the Entertainment assessment. Two dimensions (Landscape and Cultural Heritage) are compatible with the hardware component - resources that need other means to provide final benefits (Vázquez-Barquero, 1999) - and constitute operand resources (Vargo \& Lusch, 2004). Two other factors (Entertainment and $C \backslash \& S)$ match the software component since they are formed by resources that transform other means in final recompenses. Further, three other factors -SWE, Mobility and Value for Money - compose the set of efforts organized to provide benefits to people in general, the orgware.

Results also confirmed that some (but not all) personal values influence TDI assessment. People prizing self-respect tend to ascribe more importance to the receptive atmosphere, and people who prioritize excitement tend to assign more importance to the entertainment structure. On the other hand, a high preference for security influences negatively the assessment of $\mathrm{C} \backslash \& \mathrm{~S}$; in other words, the more people are interested in security, the less they evaluate the $C \backslash \& S$ structure. As it happened in San Martin \& Del Bosque (2008), in this work not all values preceded TDI evaluation: the sense of belonging, the desire for fun and enjoyment in life, the valuation of selffulfillment, to be well respected, the desire for warm relationships with others and accomplishment did not show any significant influence in the evaluation of destination image.

Results corroborate the findings of Hallmann, Zehrer \& Müller (2013) regarding the low importance of value for money in TDI studies as it did not show any influence in the likelihood to visit or to recommend the destinations; and the same happened with the influence of which on consumer intentions was not significant. Possible influences of the hardware factors (landscape and cultural heritage) in the intentions to recommend or to visit the destinations were also tested for consistency reasons, but no significance was found.

Finally, three dimensions of TDI seem to be decisive for improving the likelihood to visit and to recommend the destination: (1) a safe and welcoming environment, (2) the structure of entertainment, and (3) urban mobility. Our results permit pointing to these factors as the key inductors of visiting/recommending intentions (directly or indirectly), and due to this importance most of the tourism stakeholders attention shall be concentrated here. A positioning strategy based on the natural environment, or the architecture beauty, or on the historic culture, for example, can succeed in fixing the image of a place in consumers' minds, but this is not enough to attract tourists; the key factors for consumers' decision in this case are safety, population receptivity, mobility and the entertainment structure.

This study improves theory and shall be of interest to both academics and managers. For academics, we offer an encouraging insight to advance TDI studies, a construct that still requires deeper examination. Managers can find here an interesting reference when working in destination competitiveness or positioning strategies. Our results are limited by the sample size, which did not permit deeper inference due to the large numbers of variables in the TDI scale. Other studies are strongly encouraged to replicate our findings in other contexts and, more importantly, with samples large enough to permit separate evaluations for experienced tourists (people who have already visited the evaluated destination) and potential ones (people who have not visited the destination). The merit of this work is that is sets foot into an underexplored area of research, but the authors acknowledge that it is just a beginning, an exploratory work that requires many replications and improvements.

\section{References}

Anjos, F. A. dos, Pereira, M. de L., \& Tennenberg, F. F. P. Von. (2017). Evaluation of the image of a coastal tourism destination in Brazil. International Journal of Tourism Cities, 3(4), 324-338. https://doi.org/https:// doi.org/10.1108/IJTC-09-2016-0032

Baloglu, S., \& McCleary, K. W. (1999). A model of destination image formation. Annals of Tourism Research, 26(4), 868-897. https://doi.org/10.1016/S0160-7383(99)00030-4

Beerli, A., \& Martín, J. D. (2004). Factors influencing destination image. Annals of Tourism Research, 31(3), 657-681. https://doi.org/10.1016/j.annals.2004.01.010

Brown, T. A. (2006). Confirmatory factor analysis for applied research. New York: The Guilford Press.

Buhalis, D. (2000). Marketing the competitive destination of the future. Tourism Management, 21(1), 97-116. https://doi.org/10.1016/S02615177(99)00095-3 
Byon, K. K., \& Zhang, J. J. (2010). Development of a scale measuring destination image. Marketing Intelligence \& Planning, 28(4), 508-532. https://doi.org/10.1108/02634501011053595

Carniello, M. F., \& Santaella, L. A. (2012). A Imagem Turística de São Sebastião (SP). Caderno Virtual de Turismo, 12(3), 287-308. Retrieved from http://www.ivt.coppe.ufrj.br/caderno/index.php/caderno/article

\section{/view/678/331}

Chagas, M. Das. (2008). Imagem de destinos turísticos: uma discussão teórica da literatura especializada. Turismo-Visão E Ação, 10(3), 435$455 . \quad$ Retrieved from http://www6.univali.br/seer/index.php/rtva/article/view/774

Chagas, M. Das. (2009). Formação da Imagem de Destinos Turísticos: Uma Discussão dos Principais Modelos Internacionais.

Chagas, M. Das. (2010). Análise da relação causal entre imagem de destinos, qualidade, satisfação e fidelidade: um estudo de acordo com a percepção do turista nacional no destino turístico Natal. Igarss 2014, (1), 1-5. https://doi.org/10.1007/s13398-014-0173-7.2

Chagas, M. Das, Sampaio, L. M. B., \& Santos, K. E. B. (2013). Análise da influência da imagem de destinos na satisfação e fidelidade a destinações de turismo de sol e praia: um estudo em Natal/RN. Revista Brasileira de Pesquisa Em Turismo, 7(2).

Chen, C.-C., Lin, Y.-H., Gao, J., \& Kyle, G. (2015). Developing a MarketSpecific Destination Image Scale: A Nomological Validation Approach. Tourism Analysis, 20(1), 3-12. https://doi.org/10.3727/108354215X14205687167428

Echtner, C. M., \& Ritchie, J. B. (2003). The Meaning and Measurement of Destination Image. The Journal of Tourism Studies, 14(1), 37-48. https://doi.org/10.1177/004728759303100402

Ekinci, Y., Sirakaya-Turk, E., \& Baloglu, S. (2007). Host image and destination personality. Tourism Analysis, 12(5-6), 433-446. https://doi.org/10.1108/17506180710729619

Fakeye, P. C., \& Crompton, J. L. (1991). Image Differences between Prospective, First-Time, and Repeat Visitors to the Lower Rio Grande Valley. Journal of Travel Research, 30(2), 10-16. https://doi.org/10.1177/004728759103000202

Gallarza, M. G., Saura, I. G., \& García, H. C. (2002). Destination image. Annals of Tourism Research, 29(1), 56-78. https://doi.org/10.1016/S0160-7383(01)00031-7

Gartner, W. C. (1993). Image Formation Process. Journal of Travel \& Tourism Marketing, 2(2-3), 37-41. https://doi.org/10.1300/J073v02n02

Govers, R., Go, F. M., \& Kumar, K. (2007). Promoting Tourism Destination Image. Journal of Travel Research, 46(1), 15-23. https://doi.org/10.1177/0047287507302374

Gutman, J. (1982). A Means-End Chain Model Based on Consumer Categorization Processes. Journal of Marketing, 46(2), 60. https://doi.org/10.2307/3203341

Hahm, J. J., Tasci, A. D., \& Terry, D. B. (2018). Investigating the interplay among the Olympic Games image, destination image, and country image for four previous hosts. Journal of Travel \& Tourism Marketing, 0(0), 1-17. https://doi.org/10.1080/10548408.2017.1421116

Hallmann, K., Zehrer, A., \& Muller, S. (2013). Perceived destination image: An image model for a winter sports destination and its effect on intention to revisit. Journal of Travel Research, 54(1), 94-106. https://doi.org/10.1177/0047287513513161

Hudson, S., Wang, Y., \& Gil, S. M. (2010). The influence of a film on destination image and the desire to travel: a cross-cultural comparison. International Journal of Tourism Research, n/a-n/a. https://doi.org/10.1002/jtr.808

Hui, T. K., \& Wan, T. W. D. (2003). Singapore's image as a tourist destination. International Journal of Tourism Research, 5(4), 305-313. https://doi.org/10.1002/jtr.437

Jenkins, O. (1999). Understanding and measuring tourist destination. International Journal of Tourism Research, 1(1), 1-15.
Jiang, S., Scott, N., \& Ding, P. (2014). Using means-end chain theory to explore travel motivation: An examination of Chinese outbound tourists. Journal of Vacation Marketing, 21(1), 87-100. https://doi.org/10.1177/1356766714535599

Kotler, P. T., Bowen, J. T., \& Makens, J. (2014). Marketing for Hospitality and Tourism (6th Ed.). Essex: Pearson.

Lai, K., \& Li, Y. (2012). Core-periphery structure of destination image. Concept, Evidence and Implication. Annals of Tourism Research, 39(3), 1359-1379.

Madrigal, R., \& Kahle, L. R. (1994). Predicting Vacation Activity Preferences on the Basis of Value-System Segmentation. Journal of Travel Research, 32(3), 22-28. https://doi.org/10.1177/004728759403200304

Matos, N., Mendes, J., \& Valle, P. (2012). Revisiting the destination image construct through a conceptual model. Dos Algarves, An Interdisciplinary e-journal, 21, 101-117.

Mazanec, J. A. (1994). Image measurement with self-organizing maps: A tentative application to Austrian tour operators. Tourism Review, 49(3), 9-18.

Middleton, V. T. C., \& Clarke, J. (2001). Marketing in Travel and Tourism. (3rd Ed.). Butterworth-Heinemann: Oxford.

Murphy, P., Pritchard, M. P., \& Smith, B. (2000). The distinction product and its impact on traveler perceptions. Tourism Management, 21, 4352

Nghiêm-Phú, B. (2014). A review of destination image studies from 2008 to 2012. European Journal of Tourism Research, 8, 35-65.

Pereira, M. D. L. (2013). Avaliação da Imagem do Destino Turístico: fatores pessoais e estímulos na perspectiva do turista de Porto Belo (SC), Brasil. Dissertação de Mestrado - PPGTH, UNIVALI (SC), 0-144.

Pereira, M. L., Anjos, F. A., \& Añaña, E. S. (2014). Avaliação da Imagem de um Destino Turístico: o caso de Porto Belo (SC), Brasil. Anais do Seminário da Associação Nacional Pesquisa e Pós-Graduação em Turismo, Fortaleza, CE, Brasil, 11, 1-20.

Pereira, M. L., Anjos, F. A., \& Añaña, E. S. (2016). Análise da relação complexa entre os componentes da imagem de um destino turístico: estudo sobre a imagem de Balneário Camboriú (SC), Brasil. In Anais do Seminário da ANPTUR. (pp. 1-15).

Pérez-Nebra, A. R., \& Torres, C. V. (2010). Medindo a imagem do destino turístico: uma pesquisa baseada na teoria de resposta ao item. Revista de Administração Contemporânea, 14(1), 80-99.

Pike, S. (2005). Tourism destination branding complexity. Journal of Product \& Brand Management, 14(4), 258-259. https://doi.org/10.1108/10610420510609267

Pike, S. (2008). Destinaton Marketing. Oxford (UK): Elsevier Inc.

Prayag, G. (2008). Image, Satisfaction and Loyalty-The Case of Cape Town. Anatolia, 19(2), 205-224. https://doi.org/10.1080/13032917.2008.9687069

Reynolds, T. J., Gengler, C. E., \& Howard, D. J. (1995). A means-end analysis of brand persuasion through advertising. International Journal of Research in Marketing, 12(3), 257-266. https://doi.org/10.1016/0167-8116(95)00025-W

Rokeach, M. (1968). The Role of Values in Public Opinion Research.

Public Opinion Quarterly, 32(4), 547-559.

Sahin, S., \& Baloglu, S. (2011). Brand personality and destination image of Istanbul. Anatolia, 22(1), 69-88. https://doi.org/10.1080/13032917.2011.556222

San Martín, H., \& Rodríguez del Bosque, I. A. (2008). Exploring the cognitive-affective nature of destination image and the role of psychological factors in its formation. Tourism Management, 29(2), 263-277. https://doi.org/10.1016/j.tourman.2007.03.012

Saraniemi, S., \& Kylanen, M. (2011). Problematizing the Concept of Tourism Destination: An Analysis of Different Theoretical Approaches. Journal of Travel Research, 50(March 2010), 133-143. 
Schwartz, S. H., \& Bilsky, W. (1990). Toward a theory of the universal content and structure of values: Extensions and cross-cultural replications. Journal of Personality and Social Psychology, 58(5), 878891. https://doi.org/10.1037/0022-3514.58.5.878

Shani, A., Chen, P.-J., Wang, Y., \& Hua, N. (2009). Testing the impact of a promotional video on destination image change: application of China as a tourism destination. International Journal of Tourism Research, n/a-n/a. https://doi.org/10.1002/jtr.738

Stylidis, D., Shani, A., \& Belhassen, Y. (2017). Testing an integrated destination image model across residents and tourists. Tourism Management, 58, 184-195. https://doi.org/http://dx.doi.org/10.1016/j.tourman.2016.10.014

Stylos, N., Vassiliadis, C. A., Bellou, V., \& Andronikidis, A. (2016). Destination images, holistic images and personal normative beliefs: predictors of intention to revisit a destination. Tourism Management, 53, 40-60. https://doi.org/10.1016/j.tourman.2015.09.006

Tang, L. (Rebecca), Scherer, R., \& Morrison, A. M. (2011). Web SiteBased Destination Images: A Comparison of Macau and Hong Kong. Journal of China Tourism Research, 7(1), 2-19.

Tasci, A. D. A., \& Gartner, W. C. (2007). Destination Image and Its Functional Relationships. Journal of Travel Research, 45(4), 413-425.

Tosun, C., Bora, B., \& Fyall, A. (2015). Destination service quality, affective image and revisit intention: The moderating role of past experience. Journal of Destination Marketing \& Management, 4, 222234. https://doi.org/10.1016/j.jdmm.2015.08.002

Vargo, S. L., \& Lusch, R. F. (2004). Evolving to a New Dominant Logic for Marketing. Journal of Marketing, 68(1), 1-17. https://doi.org/10.1509/jmkg.68.1.1.24036

Vázquez-Barquero, A. (1999). Desarrollo, redes e innovación. Leciones sobre desarrollo endógeno. Madrid, Espanha: Pirámide, Ediciones.

Vinson, D. E., Scott, J. E., \& Lamont, L. M. (1977). The Role of Personal Values in Marketing and Consumer Behavior. Journal of Marketing, 41(2), 44. https://doi.org/10.2307/1250633

Zhang, H., Wu, Y., \& Buhalis, D. (2017). A model of perceived image, memorable tourism experiences and revisit intention. Journal of Destination Marketing \& Management, 8, 326-336.

Received: 20.09.2017

Revisions required: 15.01.2018

Accepted: 26.05.2018

\section{Guest Editors:}

- J. A. Campos-Soria

- J. Diéguez-Soto

- M. A. Fernández-Gámez 